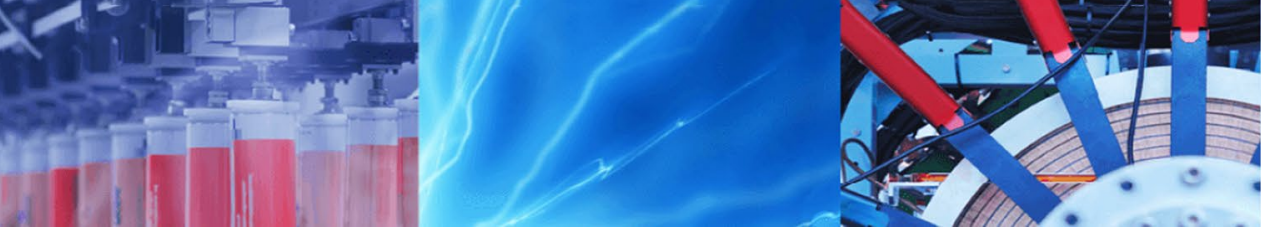

Research Article

\title{
Evaluate the effect of compost tea and some chelated micronutrients forms on black cumin productivity
}

\author{
Heba A. K. Ibrahim ${ }^{1}$ ? Rania M. R. Khater ${ }^{2} \cdot$ Rehab H. Hegab $^{1}$
}

(c) Springer Nature Switzerland AG 2018

\begin{abstract}
The effects of interaction of compost tea with chelated EDTA or humic acid micronutrients on black cumin productivity were investigated. It showed that soil drenching or foliar spray of compost tea with chelated EDTA and humic acid micronutrients increased plant height, plant dry weight, weight of seeds, oil percentage and volatile oils of seeds. Interacted compost tea significantly $(p<0.05)$ increased N, P and K percentage in seeds and straw and NPK uptake when interacted with humic form or with EDTA form. The N, $\mathrm{P}$ and $\mathrm{K}$ values for interacted foliar spray compost tea with humic form were 54,21 and $30 \mathrm{~kg} / \mathrm{f}$, and with EDTA form were 39,13 and $20 \mathrm{~kg} / \mathrm{f}$. While values for interacted soil drenching compost tea with humic form were 39, 14 and $21 \mathrm{~kg} / \mathrm{f}$, and with EDTA form were 26,10 and $15 \mathrm{~kg} / \mathrm{f}$. The difference between drenching and foliage application of compost tea with two chelated forms was not significant $(p>0.05)$ in the two seasons, for plant dry weight, weight of seeds and oil percentage. However it was significant $(p<0.05)$ with humic form in the second season for plant height and in the first season for volatile oils percentage. Compost tea when applying in conjunction with mineral fertilizers results in high performance in the availability, uptake and accumulation of nutrient elements and leading to increasing in black cumin productivity.
\end{abstract}

Keywords Compost tea $\cdot$ Black cumin $\cdot$ Nigella sativa $\cdot$ Micronutrients $\cdot$ Mineral fertilizers

\section{Introduction}

Black cumin, Nigella sativa L. plant belongs to Ranunculaceae family, common known as black cumin or black-caraway seed [36], is cultivated for seed yield and oil production. Seeds show a wide range of antibacterial, antitumor, anti-inflammatory, hypoglycemic, muscle relaxant and immune-stimulant activities $[13,28,60]$. Seeds components used in functional cosmetics and dietary supplemental products $[42,55]$. The whole seeds contain $30-35 \%$ of oil which has several uses for pharmaceutical and food industries.

In newly reclaimed soils that are usually poor in their nutrients content, foliar nutrition is widely used to correct nutrition deficiency. Application of suitable foliar fertilizer rates affect growth and yield of several medicinal plants [24] (El-Kholy et al. [19]). Foliar nutrients resulted very clear response on black cumin growth and yield components [35]. Foliar spray with $\mathrm{Fe}, \mathrm{Zn}$ and $\mathrm{Mn}$ stimulated growth characterizes and chemical constituents on $N$. sativa plants $[41,68]$. Egyptian sandy soil is characterized by poor macro- and micronutrients that negatively affect growth and productivity of medicinal plants [1]. Organic material improve soil chemical properties, decrease soil pH, increase cation exchange capacity and enhance the most nutrient, which is important for plant growth [64]. Liquid compost support metabolically dynamic process during the growth of plant and serve as a source of soluble nutrients and growth stimulants [66].

Plant nutrition is one of the most important factors that increase plant production. Micronutrients considered as a one of the most important milestones in the progress of

$\square$ Heba A. K. Ibrahim, hebaahmed286@hotmail.com | 'Soil Fertility and Microbiology Department, Desert Research Center, Cairo, Egypt. ${ }^{2}$ Medicinal and Aromatic plants Department, Desert Research Center, Cairo, Egypt.

SN Applied Sciences (2019) 1:28 | https://doi.org/10.1007/s42452-018-0031-x 
agriculture crop production [56]; they are needed in small quantities for normal plant growth and development [6, 62]. Micronutrients (i.e., $\mathrm{Cu}, \mathrm{Mn}, \mathrm{Zn}$, Fe, etc.) play an important role in crops yield and quality [57], it contribute in plants metabolic processes like, respiration, $\mathrm{N}$-fixation, and photosynthesis [29]. Fe is a part of the catalytic group for many redox enzymes, several oxidases (i.e. catalase and peroxidases), and required for the synthesis of chlorophyll. $\mathrm{Zn}$ is an activator of a variety of enzymes including alcohol dehydrogenase, carbonic anhydrase and superoxide dismutase. Cu functions as a cofactor for oxidative enzymes including cytochrome oxidase [27]. N sativa Yield responses to micronutrient application [52]. Without the use of chelates, many of these nutrients would be unavailable to plants. The word chelate comes from the Greek word "chele" which literally means "claw", and used by researchers in the 1920s because it describes the principal of grasping and holding something, which is essentially, what occurs in the process of chelation. Chelates not absorbed by the plant and can persist environments [5], and make metal cations gradually released and absorbed by plants in complexed forms [67]. Chelating agent EDTA, Ethylenediamine tetraacetate, the most common chelating agent in synthetic fertilizers, has low biodegradability $[5,12]$. Humic acid is water-soluble organic acid, naturally occurring in soil organic matter, and has many beneficial effects on soil including increase nutrients uptake [11,37]. Application of the humic acid raised N, P, K, Ca, Mg, Na, Fe, $\mathrm{Cu}, \mathrm{Zn}$ and $\mathrm{Mn}$ uptake, increased the dry weight of plants [32], increased seed yield and essential oil percentage [8].

Soil macro and microelements, enhanced by organic fertilizer [44]. Integrated plant nutrient supply including organic materials, enhance efficiency of micronutrients used in fertilizers and restoring soil fertility [63]. It might be persistent for longer periods of use when compared with inorganic fertilizers [61]. Foliar spray increased yield, levels of fixed, and essential oil content in black cumin plants [26]. Foliar nutrition is helping in a specific nutrition deficiency, especially in newly reclaimed soil where it is usually poor in their nutrients content. Compost tea as an organic fertilizer contains nutrients and micronutrients that are biologically available to be consumed by soil microbes and plants [25]. Plant leaves absorb nutrients easily from foliar fertilizer resulting increase in crops production [6], so the vegetative growth of Nigella plants increased significantly with foliar fertilizer comparing with soil-applied fertilizer [7]. Yield characteristic (plant height, fresh and dry weight, weight of seeds and oil percentage) of Borage plants Increased significantly with adding compost tea [18]. In addition, compost tea increased the carbohydrate content in turnip roots [20] and enhanced the percentage of Nitrogen and Phosphorus in sugar beet plant by 126 and $225 \%$, respectively [30].

Natural extracts enhanced the efficiency of the nutrient solution and enhanced the $N$. sativa growth [48] The aim of the study was to investigate the interaction effect of compost tea with chelated forms EDTA and humic acid micronutrient solutions on black cumin productivity, in addition to some macronutrients availability and content.

\section{Materials and methods}

\subsection{Chemical analysis of compost}

Samples digested according Cottenie et al. [17], and analyzed for N, P, K and micronutrients. Organic matter content was determined according to Chapman and Pratt [15]. Total nitrogen was determined according to Chapman and Pratt [16]. pH value was measured according to Jodice et al. [31] (in 1compost:5water ratio). Phosphorus was determined according to Trough and Mayer [65] (Table 1).

\subsection{Compost tea production}

Aerated compost tea produced by mixing mature compost made by El-Arabeya for Organic Fertilizer Factory with distilled water in ratio of $1: 5(\mathrm{w} / \mathrm{v})$ and supplemented with $2 \%$ molasses for microbial growth stimulation. The entire contents were continuously aerated at room temperature with a fish-tank bubbling-pump for $72 \mathrm{~h}$.

\subsection{Microbial and chemical analysis of compost tea}

Total microbial count and microbial analysis for compost tea was calculated using serial dilatations and total plate count technique. Nutrient medium used for total microbial count, King B medium used for Pseudomonas count, Potato Dextrose Agar medium used for fungi and yeast count, MacConkey medium used for Enterobactereacea
Table 1 Chemical analysis of compost

\begin{tabular}{|c|c|c|c|c|c|c|c|c|c|}
\hline \multirow[t]{3}{*}{$\mathrm{pH}(1: 5)$} & \multirow[t]{3}{*}{$\mathrm{EC}(1: 5)(\mathrm{ds} / \mathrm{m})$} & \multirow[t]{3}{*}{$\mathrm{C} / \mathrm{N}$} & \multicolumn{7}{|c|}{ Total nutrients } \\
\hline & & & \multicolumn{7}{|l|}{ ppm } \\
\hline & & & $\mathrm{N}$ & $P$ & $\mathrm{~K}$ & $\mathrm{Fe}$ & $\mathrm{Mn}$ & $\mathrm{Zn}$ & $\mathrm{Cu}$ \\
\hline 8.1 & 6.8 & 16.8 & 14,600 & 7800 & 11,200 & 325 & 146 & 78.5 & 35.4 \\
\hline
\end{tabular}


Table 2 Compost tea microbial total count

\begin{tabular}{lllll}
\hline Time $(\mathrm{h})$ & 0 & 24 & 48 & 72 \\
\hline $\mathrm{CFU} / \mathrm{ml} \times 10^{5}$ & 0.51 & 236 & 383 & 145 \\
\hline
\end{tabular}

Table 3 Microbiological analysis of compost tea

\begin{tabular}{llllll}
\hline $\begin{array}{l}\text { Total } \\
\text { bacteria } \\
\text { (CFU/ }\end{array}$ & $\begin{array}{l}\text { Fungi } \times 10^{2} \\
\text { (CFU/ml) }\end{array}$ & $\begin{array}{l}\text { Yeast } \\
\text { (CFU/ } \\
\mathrm{ml})\end{array}$ & $\begin{array}{l}\text { Pseu- } \\
\text { domonas } \\
\text { spp. } \times 10^{2} \\
(\mathrm{CFU} / \mathrm{ml})\end{array}$ & $\begin{array}{l}\text { Entero- } \\
\text { bacte- } \\
\text { reacea } \\
\text { (CFU/ } \\
\mathrm{ml})\end{array}$ & $\begin{array}{l}\text { Strepto- } \\
\text { coccus } \\
\text { (CFU/ } \\
\mathrm{ml})\end{array}$ \\
\hline U.C. & 115 & 0 & 21 & 0 & 0 \\
\hline
\end{tabular}

U.C. uncountable

determination (Tables 2, 3). Chemical analysis was done according to Cottenie et al. [17] (Table 4).

\subsection{Chelating forms preparation}

Micronutrients solution was as sulfate form with concentration: 300 ppm for Fe, 100 ppm for Mn, 50 ppm 1 for $Z n$, and $50 \mathrm{ppm}$ for $\mathrm{Cu}$. The chelating agents were EDTA and humic acid.

\subsection{Initial chemical and physical properties for soil}

Soil analyses were done according to Klute [39] (Table 5).

\subsection{Chemical analysis for irrigation water}

Water analyses were done according to Chapman and Pratt $[15,16]$ (Table 6).

\subsection{Field experiment}

A field experiment was carried out in Baluza research station of the Desert Research Center. The experiment geographic location is coordinates: $31^{\circ} 3^{\prime} 0^{\prime \prime} \mathrm{N}, 32^{\circ} 36^{\prime} 0^{\prime \prime} \mathrm{E}$, during two successive winter growing seasons in 2016 and 2017. Compost tea at age $48 \mathrm{~h}$ and two chelated micronutrients forms, previously prepared, were used. Eight treatments applied as follow: Foliar spray: compost tea (CT), EDTA, humic acid, CT + EDTA (1:1) and CT + humic acid (1:1). Soil drench: $C T, C T+$ foliar EDTA (1:1) and $C T+$ foliar humic acid (1:1). The eight treatments and the control applied two times, at the tillering stage ( 35 days from sowing) and at the booting stage (70 days from sowing), all treatments as a foliar spray or soil drench were $15 \mathrm{ml}$ per each plant. The experimental field was irrigated by drip irrigation system. Black Cumin seeds were sowing during 15 November in rows spacing
Table 4 Nutrient contents of compost tea

\begin{tabular}{lllllll}
\hline \multicolumn{2}{l}{ Nutrients (ppm) } & & & & & \\
\hline $\mathrm{N}$ & $\mathrm{P}$ & $\mathrm{K}$ & $\mathrm{Fe}$ & $\mathrm{Zn}$ & $\mathrm{Mn}$ & $\mathrm{Cu}$ \\
\hline 2025 & 289 & 1725 & 1.36 & 1.95 & 0.86 & $\mathrm{~N}$ \\
\hline
\end{tabular}

$N$ not detected

Table 5 Initial status of some chemical and physical properties of the experimental soil

Chemical properties

Depth $(\mathrm{cm}) \quad \mathrm{pH}^{\mathrm{a}} \quad \mathrm{EC}(\mathrm{ds} / \mathrm{m})^{\mathrm{b}} \quad$ Soluble ions in saturated soil extract $(\mathrm{ppm})$

Available nutrients

(ppm)

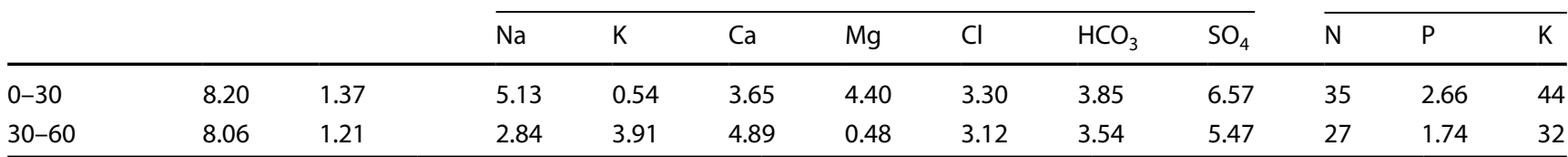

Physical properties

\begin{tabular}{lllll}
\hline Depth $(\mathrm{cm})$ & \multicolumn{2}{l}{ Particle size distribution $(\%)$} & & Texture class \\
\cline { 2 - 5 } & Sand & Silt & Clay & Sandy \\
\hline $0-30$ & 89.12 & 6.34 & 4.54 & Sandy \\
$30-60$ & 90.73 & 5.56 & 3.71 & \\
\hline
\end{tabular}

${ }^{\mathrm{a}} \mathrm{pH}$ in saturated soil paste

${ }^{b}$ Electrical conductivity in saturated soil extract 
Table 6 Chemical analysis for irrigation water

\begin{tabular}{|c|c|c|c|c|c|c|c|c|c|c|}
\hline \multirow[t]{2}{*}{$\mathrm{pH}$} & \multirow[t]{2}{*}{ E.C. $(p p m)$} & \multirow[t]{2}{*}{ S.A.R } & \multicolumn{4}{|c|}{ Soluble cations (ppm) } & \multicolumn{4}{|c|}{ Soluble anions (ppm) } \\
\hline & & & $\mathrm{Ca}^{++}$ & $\mathrm{Mg}^{++}$ & $\mathrm{Na}^{+}$ & $\mathrm{K}^{+}$ & $\mathrm{CO}_{3}^{-}$ & $\mathrm{HCO}_{3}^{-}$ & $\mathrm{SO}_{4}^{=}$ & $\mathrm{Cl}^{-}$ \\
\hline 7.45 & 1456 & 3.80 & 58 & 38.4 & 197.8 & 23.4 & 30 & 342.72 & 100.8 & 266.25 \\
\hline
\end{tabular}

$50 \mathrm{~cm}$ apart and $15 \mathrm{~cm}$ between seed hills (17,500 plant/ fed). All treatments received $37 \mathrm{~kg} \mathrm{~K}_{2} \mathrm{O} / \mathrm{fed}$ as potassium sulfate, $60 \mathrm{~kg} \mathrm{~N} / \mathrm{fed}$ as ammonium sulfate and $\mathrm{K}$ fertilizer in two equal doses with $\mathrm{N}$ fertilizer and Phosphorus as super phosphate $\left(15.5 \% \mathrm{P}_{2} \mathrm{O}_{5}\right)$ at the rate of $50 \mathrm{~kg} \mathrm{P} \mathrm{O}_{5}$ $\mathrm{fed}^{-1}$ during the soil preparation. Other agricultural practices were done as recommended by Ministry of Agriculture. The experiment was arranged as randomized complete block design with three replicates. Soil samples were collected from the studied plots at two depths $(0-30 \mathrm{~cm}$ and $30-60 \mathrm{~cm})$ before initiating the experiment for physical and chemical analysis. Mature Black Cumin plants were harvested at the end of April. Crop was harvested manually. Grains were separated from straw and weighed in the field, and samples were collected for further analysis. Plant height, plant dry weight, seed weight per plant, oil content, and volatile oils were determined.

\subsection{Fixed oil and volatile oils assay}

Seeds fixed oil per plant was extracted by hexane and determined according to Pearson [53]. The percentage and yield of volatile oils determined in the ground seeds by water distillation using a Clevenger-type apparatus according to Pharmacopoeia [54].

\subsection{Nutrients content in plants}

Collected samples were dried in a hot air oven at $70{ }^{\circ} \mathrm{C}$ for 3 days and ground. The samples were wet digested in $\mathrm{H}_{2} \mathrm{SO}_{4}-\mathrm{H}_{2} \mathrm{O}_{2}$ mixture for $\mathrm{N}, \mathrm{P}, \mathrm{K}$ and micronutrients analysis.

\subsection{Statistical analysis}

The analysis of variance (ANOVA) was used to determine the effects of treatments on the generated data. Least significant difference (LSD) was used to test the differences between means at $p<00.05$ and $p<0.01$.

\section{Results and discussion}

\subsection{Effect of compost tea and chelated micronutrients on growth parameters of black cumin}

\subsubsection{Plant height}

All treatments increased plant height, highly significant $(p<0.05)$ in two seasons, comparing with control (Fig. 1). The highest values of plant height came from interaction with compost tea. The values were highly significant $(p<0.01)$ in both of soil drench and foliar spray treatments comparing with chelated humic acid foliar alone. Interaction between chelated humic acid and compost tea increased plant height by $227 \%$ and $224 \%$ as a foliar spray, and by $208 \%$ and $207 \%$ as soil drench, at season one and two respectively, while foliar chelated humic acid increased plant height by $171 \%$ and $164 \%$ at season one and two respectively. The interaction between chelated EDTA and compost tea significantly $(p<0.05)$ increased plant height by $189 \%$ and $192 \%$ as foliar spray and by $175 \%$ and $167 \%$ as a soil drench, at season one and two respectively. While chelated EDTA alone increased plant height by $137 \%$ and $150 \%$ at season one and two respectively. Difference
Fig. 1 Effect of compost tea and chelated micronutrients on plant height. * Significant $(p<0.05) ; *$ highly significant $(p<0.01)$

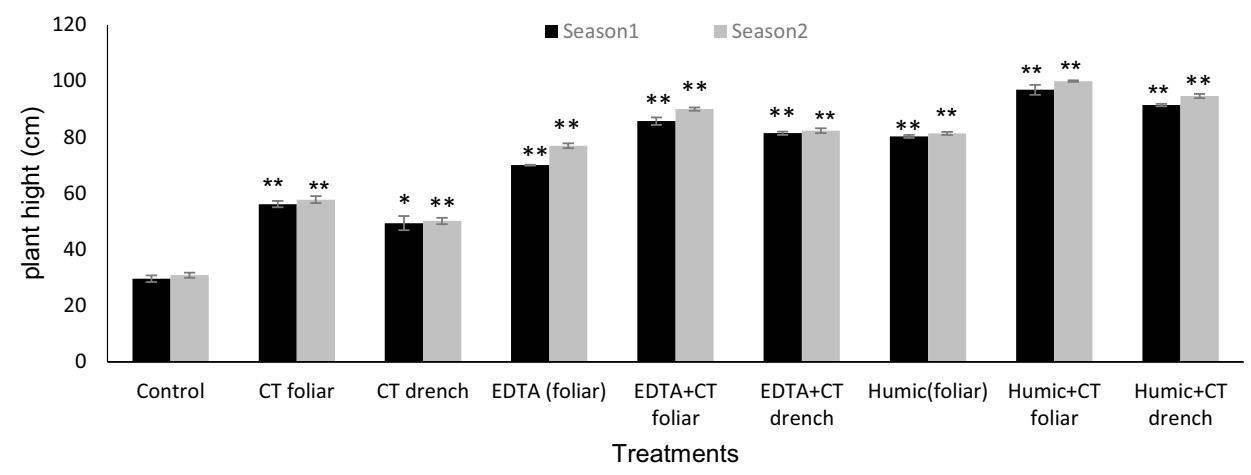


between drenching and foliage application of compost tea with two chelated forms was not significant $(p>0.5)$ in the second season.

\subsection{Plant dry weight}

Plant dry weight increased for all treatments comparing with control (Fig. 2). The interaction of chelates with compost tea, significantly $(p<0.05)$, revealed the highest dry weight. The values were significantly high $(p<0.01)$ in both of soil drench and foliar spray treatments comparing with chelated forms. The humic interacted with compost tea increased the dry weight by $287 \%$ and $262 \%$ with foliar apply and by $230 \%$ and $239 \%$ by soil drenching at season 1 and 2, respectively, while chelated humic alone increased it only by $73 \%$ at both seasons. The EDTA when interacted with compost tea increased the dry weight by $199 \%$ and $145 \%$ with foliar apply and by $152 \%$ and $116 \%$ by soil drenching at season 1 and 2, respectively, while chelated EDTA alone increased it only by $60 \%$ and $43 \%$ at season 1 and 2 , respectively. The difference between drenching and foliage application of compost tea with two chelated forms was significant $(p>0.05)$ in the two seasons.

\subsection{Weight of seeds}

Weight of seeds increased for all treatments comparing with control (Fig. 3). The interaction of chelates with compost tea, significantly $(p<0.05)$, increased the seeds weight in both of soil drench and foliar spray treatments comparing with chelated forms. When humic interacted with compost tea, increased the seeds weight by $141 \%$ and $207 \%$ with foliar apply, and by $99 \%$ and $151 \%$ by soil drenching at season 1 and 2, respectively. When EDTA interacted with compost tea, increased the seeds weight by $88 \%$ and $129 \%$ with foliar apply, and by $109 \%$ and $161 \%$ by soil drenching at season 1 and 2, respectively. Chelated humic and chelated EDTA alone increased seeds weight only by $61 \%$ and $80 \%$ and $41 \%$ and $60 \%$ at season 1 and 2 respectively. The difference between drenching and foliage application of compost tea with two chelated forms was not significant $(p>0.05)$ in the two seasons.

\subsection{Oil percentage}

All treatments increased oil content, significantly $(p<0.05)$. Interacted humic with compost tea, affected oil percentage positively to increase by $193 \%$ and $188 \%$ with foliar apply, and by $162 \%$ by soil drenching at season 1 and 2 , respectively. When EDTA interacted with compost tea, seeds weight increased by $134 \%$ and $118 \%$ with foliar
Fig. 2 Effect of compost tea and chelated micronutrients on plant dry weight. *Significant $(p<0.05) ;{ }^{* *}$ highly significant $(p<0.01)$

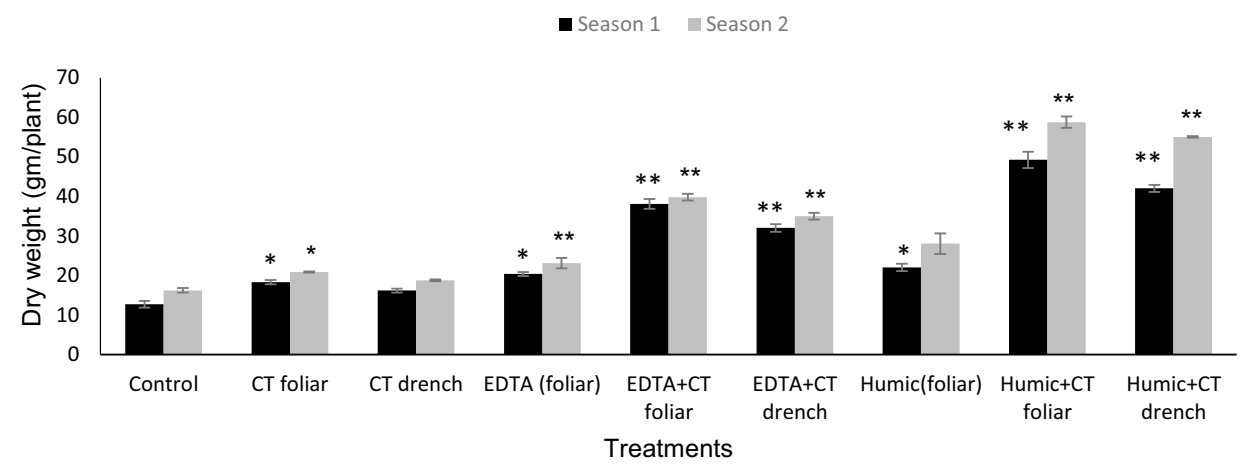

Fig. 3 Effect of compost tea and chelated micronutrients on weight of seeds. *Significant $(p<0.05) ;{ }^{* *}$ highly significant $(p<0.01)$

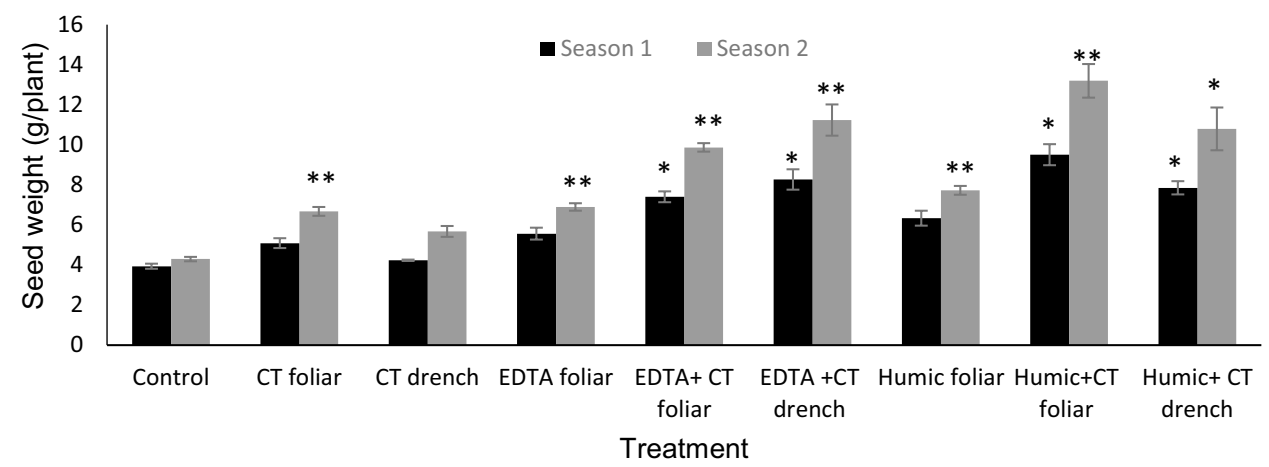

SN Applied Sciences A SPRINGER NATURE journa 
apply, and by $111 \%$ and $100 \%$ by soil drenching at season 1 and 2, respectively. Chelated humic and chelated EDTA alone increased seeds weight only by $98 \%$ and $80 \%$ and $80 \%$ and $78 \%$ for foliar spray and soil drench at season 1 and 2 respectively. There was no significant between drenching and foliage application of compost tea with two chelated forms at the two seasons. Foliar fertilizer had a significant $(p<0.05)$ effect on fixed oil percentage, it increased by $30.60 \%$ in Nigella plants [26] (Fig. 4).

\subsection{Volatile oils $\%$}

All treatments increased volatile oils in two seasons. Interacted compost tea with humic or EDTA as a foliar spray or soil drench, significantly $(p<0.05)$, increased volatile oils Comparing with control. Volatile oils were increased by $83 \%$ and $69 \%$ when humic integrated with foliar compost tea and by $52 \%$ and $31 \%$ with soil drenching compost tea, while only by $31 \%$ and $11 \%$ with humic chelate alone at seasons 1 and 2 respectively. EDTA increased volatile oils by 21 and $14 \%$, while when integrated with compost tea increased volatile oils by 62 and $39 \%$ and 45 and $61 \%$ for foliar application and soil drenching respectively at seasons 1 and 2 . There was a significant $(p<0.05)$ difference between interacted humic with compost tea as a foliar and as soil drench in season 1 (Fig. 5).
The combination of organic and inorganic fertilizers increase the fertilizer use efficiency to a considerable extent and gave the best values for all tested parameters [49] (Mohankumar and Gowda [47]). Chelated forms of humic acid or EDTA when integrated with foliar compost tea gave the highest values, for black cumin height, dry weight, weight of seeds, oil percentage and volatile oil percentage, comparing with integration with soil drenching compost tea and comparing with the chelated micronutrients forms alone. In Borage plants, using compost tea significantly increased plant height, fresh and dry weight, weight of seeds and oil percentage [18]. Compost tea contains many beneficial microbes and nutrients of compost but more easily applied to plants, and could be used as an agent for promoting plant growth (Kim et al. [38]). The foliar application of mineral nutrients offers a method of supplying nutrients to plants that are more efficiently than methods involving root application [21]. Spray plants with compost tea is more effective for delivering nutrients than drenching the soil $[9,23]$. Humic increased plant height [4], and mineral fertilization with compost tea increased plant dry weight by $124 \%$ comparing with the application of them individually [25]. Foliar fertilizer significantly increased fixed oil percentage in Nigella plants [26]. Pant et al. [51] mentioned that compost tea increased dry weight of pak choi plants (Brassica rapa cv Bonsai) more
Fig. 4 Effect of compost tea and chelated micronutrients on oil \%. *Significant; **highly significant
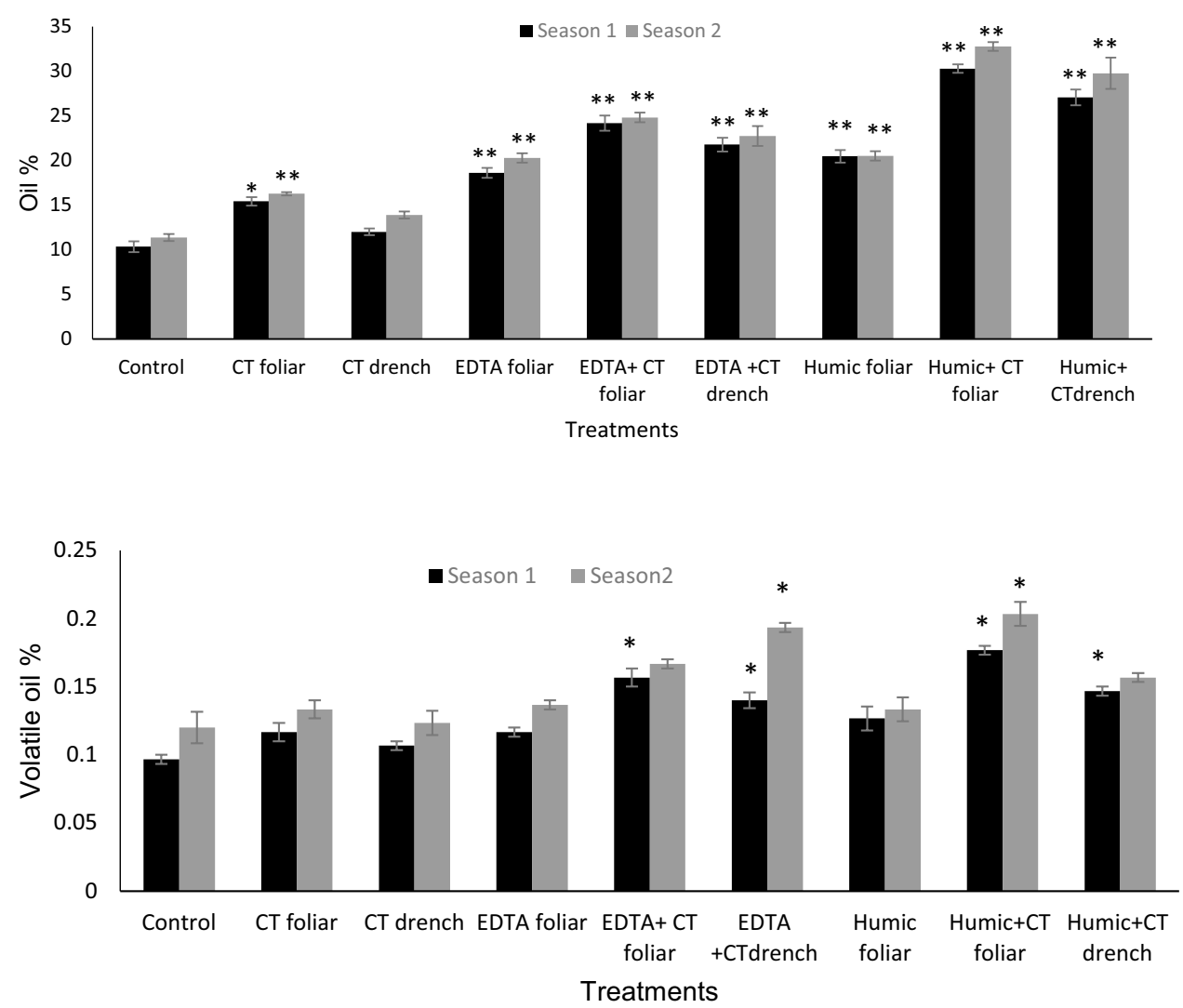

Fig. 5 Effect of compost tea and chelated micronutrients on volatile oil \%. *Significant $(p<0.05)$ 
than mineral nutrients did, while in our results with black cumin plant, compost tea alone did not.

\subsection{Nutrients content in plants}

NPK percentage in black cumin seeds and straw and uptake in black cumin seeds Kilogram/fedan for season one were assayed.

\section{7 $\mathbf{N}$ content in seeds and straw}

All treatments significantly $(p<0.05)$ increased the percentage of $\mathrm{N}$, in both black cumin seeds and straw (Figs. 6 , 7). Compost tea when integrated with EDTA or humic acid chelated micronutrients forms, significantly high $(p<0.1)$, increased N\% by 167 and $121 \%$ and 150 and $190 \%$ in seeds, and by 413 and $225 \%$ and 270 and $196 \%$ in straw, with foliar and soil drenching compost tea respectively. Chelated EDTA increased by 102 and $122 \%$, and humic acid by 114 and $143 \%$ for seeds and straw respectively. Difference between integrated compost tea as a foliar and as a soil drenching was significant $(p<0.05)$.

\subsection{P content in seeds and straw}

Figures 8 and 9 showed that, integrated treatments of compost tea, as a foliar or soil drench, increased $\mathrm{P} \%$ in seeds highly significant $(p<0.01)$ with EDTA by 183 and $113 \%$. Difference between EDTA and compost tea as a soil drench or as a foliar spray was non-significant. Adding compost tea to humic as foliar spray increased the P\% in seeds significantly $(p<0.05)$ by $246 \%$, while as a soil drench was non-significant. Difference between humic and compost tea as a soil drench or as a foliar spray was significant $(p<0.05)$. Integrated treatments of compost tea, as foliar increased P\% in straws significantly $(p<0.05)$ with humic by $352 \%$, while as a soil drench was non-significant. Difference between humic and compost tea as a soil drench or as a foliar spray was highly significant $(p<0.01)$.

\section{9 $\mathrm{K}$ content in seeds and straw}

Foliar compost tea integrated with EDTA increased the $\mathrm{K} \%$ highly significant $(p<0.01)$ in black cumin seeds by $608 \%$, while integrated drenching compost
Fig. 6 Effect of compost tea and chelated micronutrients on N\% in black cumin seeds. **Highly significant $(p<0.01)$
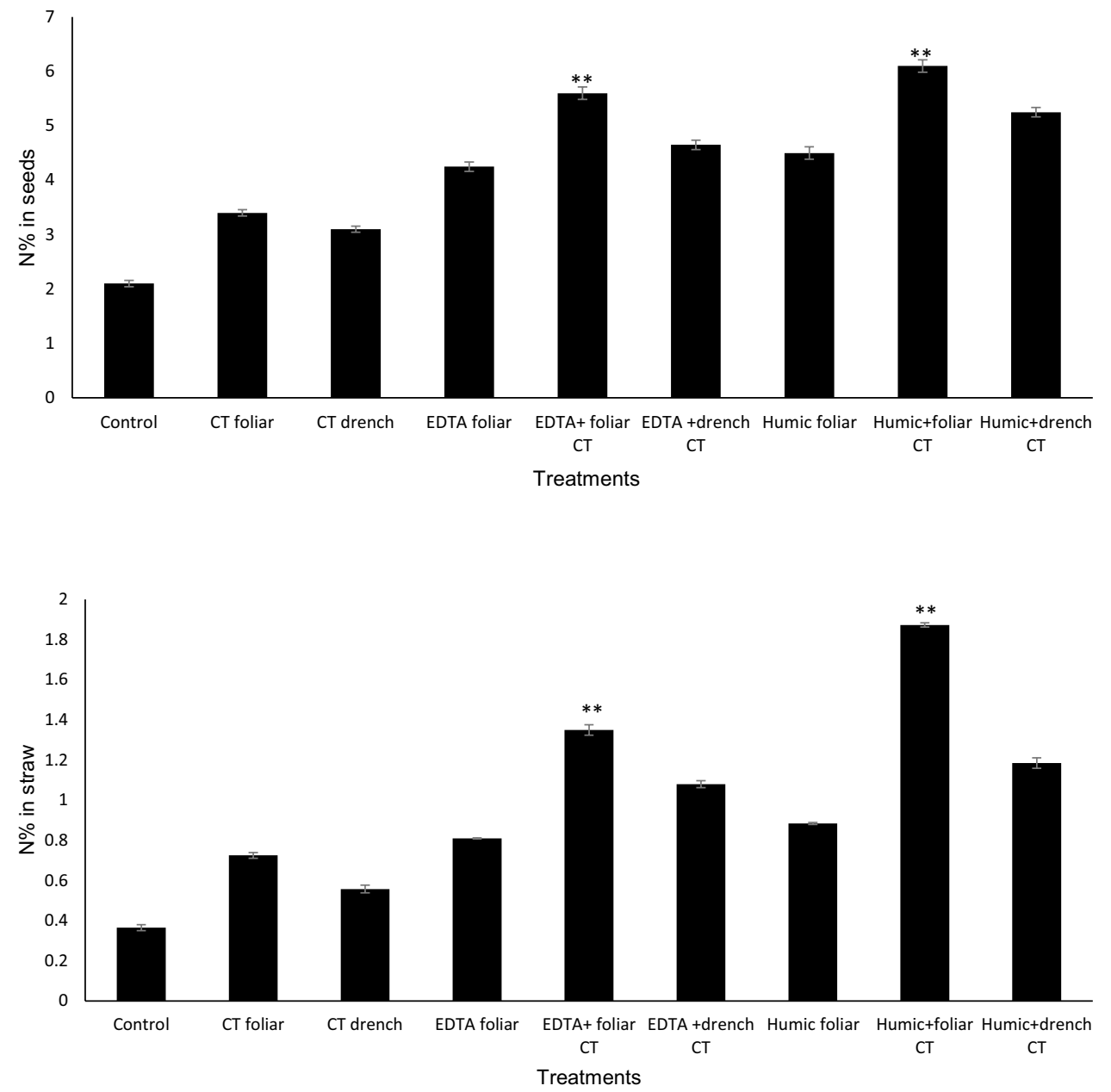

Fig. 7 Effect of compost tea and chelated micronutrients on $\mathrm{N} \%$ in black cumin straw. **Highly significant $(p<0.01)$ 
tea increased it significantly $(p<0.05)$ by $531 \%$, and the difference between foliar and soil drenching integrated compost tea was non-significant. In addition, Foliar compost tea integrated with humic increased the $\mathrm{K} \%$ highly significant $(p<0.01)$ in black cumin seeds by $704 \%$, while integrated drenching compost tea increased it significantly by $556 \%$, and the difference between foliar and soil drenching integrated compost tea was significant $(p<0.05)$. In Straw, foliar compost tea integrated with EDTA or with humic increased the $\mathrm{K}$ percentage significantly high $(p<0.01)$ by $266 \%$ and $283 \%$ respectively, while with drenching compost tea the increment was non-significant (Figs. 10, 11).

\subsection{Nutrients uptake in black cumin seeds}

NPK uptake increased in all treatments comparing with control, the highest values came when compost tea integrated with humic or EDTA as a foliar spray, and then when integrated as a soil drenching (Fig. 12). The NPK uptake values were 54,21 and $30 \mathrm{~kg} / \mathrm{f}, 39,13$ and $20 \mathrm{~kg} / \mathrm{f}$, for integrated foliar compost tea with humic and EDTA respectively. And were 39, 14 and $21 \mathrm{~kg} / \mathrm{f}$ and 26,10 and $15 \mathrm{~kg} / \mathrm{f}$ for integrated drenching compost tea with humic and EDTA respectively.

Availability of nutrients of organic fertilizers depends on the dynamics of the mineralization process [45]. Compost tea enhancing the uptake and accumulation of nutrient elements in the plant [58]. It is a primary nutrient source, and when applying in conjunction with mineral fertilizers
Fig. 8 Effect of compost tea and chelated micronutrients on $\mathrm{P} \%$ in black cumin seeds. **Highly significant $(p<0.01)$
Fig. 9 Effect of compost tea and chelated micronutrients on $\mathrm{P} \%$ in black cumin straw. ${ }^{* * H i g h l y ~ s i g n i f i c a n t ~}(p<0.01)$
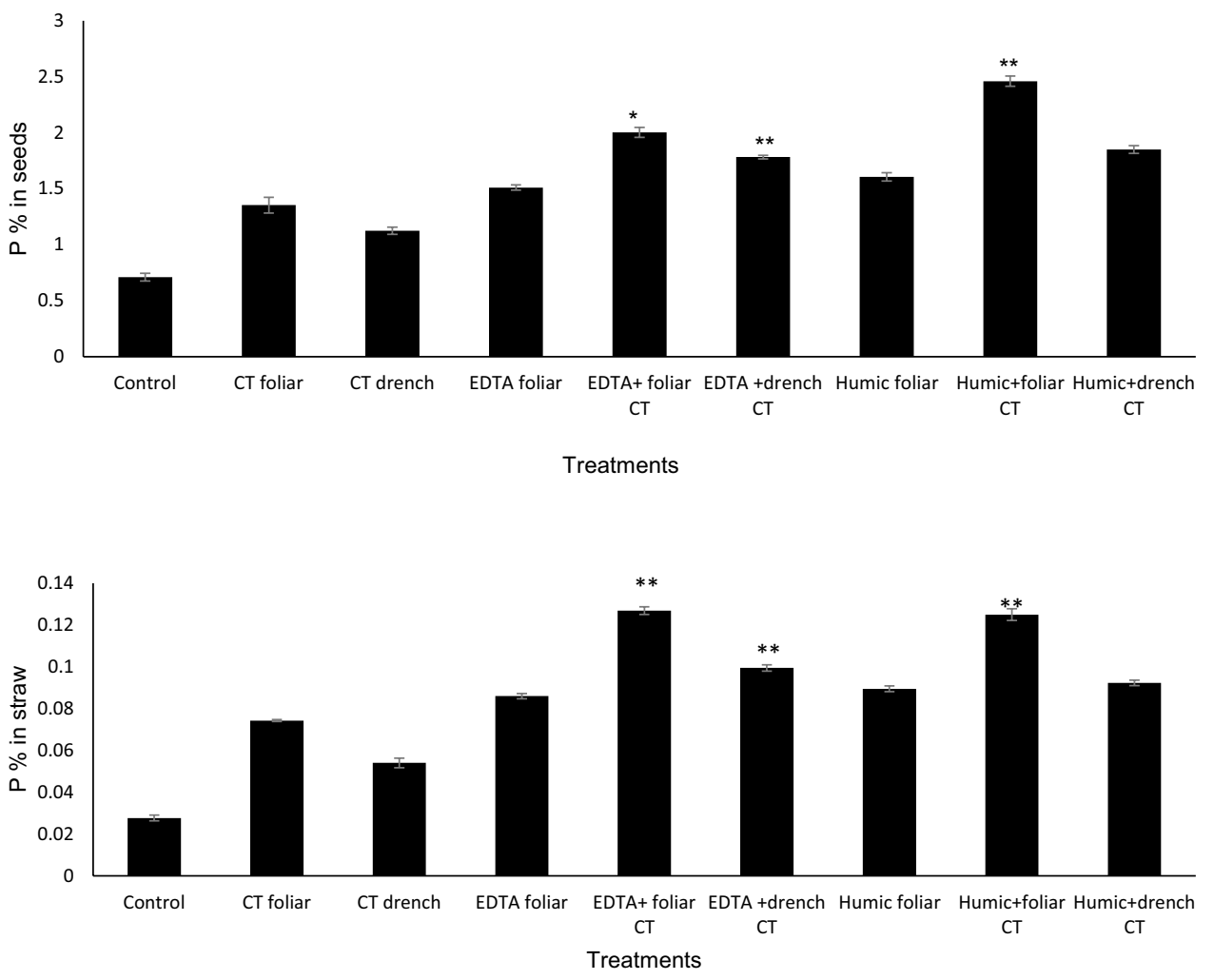

Fig. 10 Effect of compost tea and chelated micronutrients on $\mathrm{K} \%$ in black cumin seeds

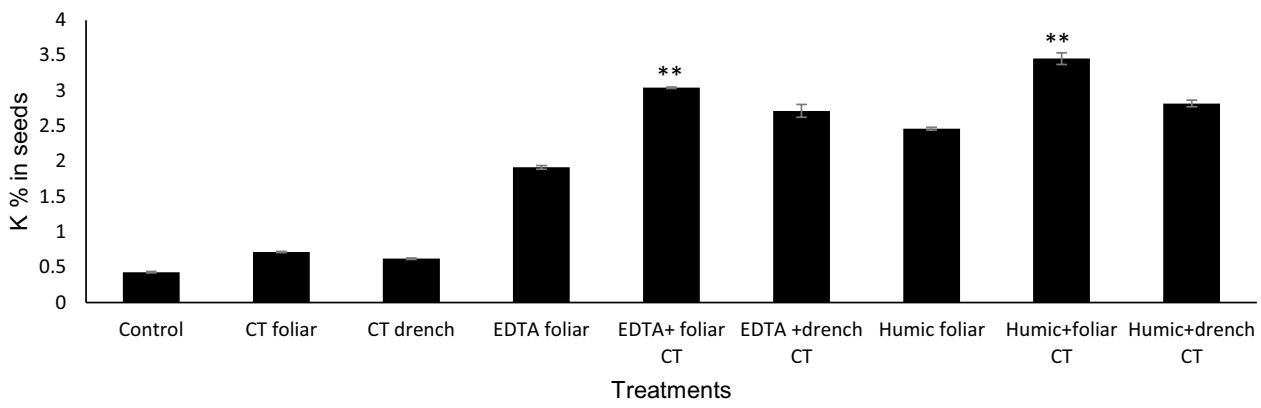


Fig. 11 Effect of compost tea and chelated micronutrients on $\mathrm{K} \%$ in black cumin straw. **Highly significant $(p<0.01)$
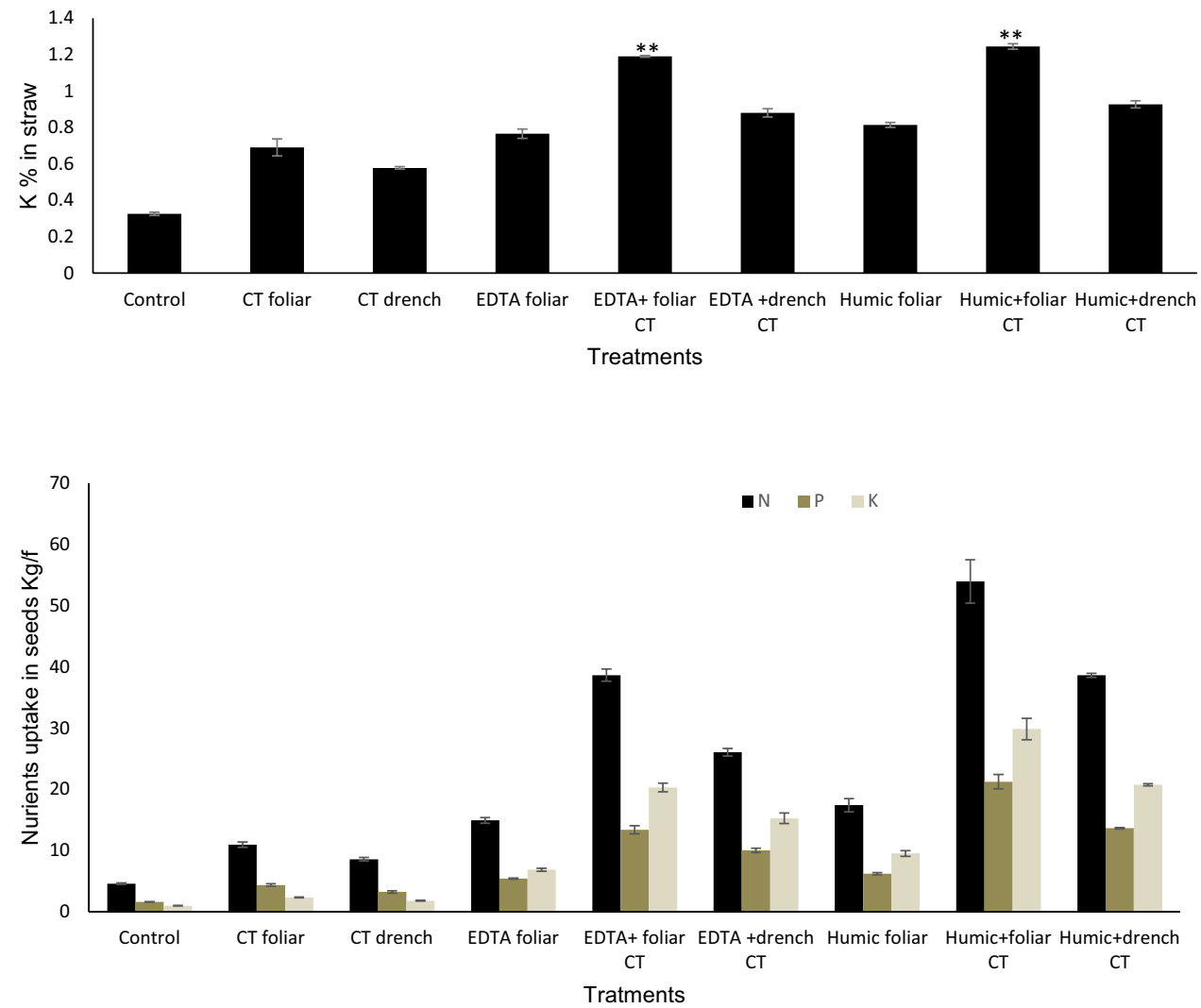

Fig. 12 Effect of compost tea and chelated micronutrients on nutrients uptake in black cumin seeds results in high performance. For Basil [34], Borage [18], Sugar Beet [30] and Peppers, Cucumbers and Sweet Onions [55].

Foliar nutrition is helping in a specific nutrition deficiency. Compost tea contains nutrients and micronutrients in easily available form to be consumed by plants and soil microorganisms besides supporting the metabolism of plant growth $[25,66]$.

Biologically active metabolites such as humic acids and plant growth regulators, as well as water extractable mineral nutrients present in compost would be extracted during the brewing process of compost tea production $[10,50]$. These compounds increasing soils microbial contents, enhance root development, extend nutrient supplying capacity, reduce mineral nutrient loss, and improve plant growth (Carpenter-Boggs [14]), [40]. Compost tea increasing N, P and K concentration and its uptake by plants because as a role of organic extracts which develop the root system of plant and improved nutrient uptake $[3,46]$. Compost tea increased permeability of cellular membranes in plants to minerals [33]; promote root absorption of nutrients [22]. Foliar fertilization with compost tea allows nutrients to be absorbed by the plants directly through stomata on their leaf surfaces resulting increase in nutrients uptake by plants and crops production [6]. Foliar application of compost tea increased the time stomata stay open, reducing loss from the leaf surface, so the availability of mineral nutrients is higher for foliar than drench application [43]. Highly nutrients concentrated compost tea when combined with mineral fertilization increased $\mathrm{N}$, $\mathrm{P}$ and $\mathrm{K}$ concentrations and their uptake [2].

\section{Conclusion}

Conjunction of compost tea, as a foliar spray or soil drenching with chelates forms EDTA and humic acid micronutrient solutions increased plant height, dry weight and weight of seeds, oil percentage and volatile oils in black cumin. High performance in the availability, uptake and accumulation of nutrients occurred. NPK percentage increased in seeds and straw of black cumin. Compost tea enhanced the effect of micronutrients on black cumin productivity and oil contents beside the uptake of NPK, when applied in a combination.

\section{Compliance with ethical standards}

Conflict of interest The authors declare that they have no conflict of interest. 


\section{References}

1. Abd-Allah AM, Adam SM, Abou-Hadid AF (2001) Productivity of green cowpea in sandy soil as influenced by different organic manure rates and sources. Egypt J Hortic Sci 28(3):331-340

2. Abd El-Hameed KA (2008) Impact of including straw in preparing compost tea for organic farming. M.Sc. thesis, Faculty of Agriculture, Mansoura University

3. Abd El-Kader MG, El-Shaboury MG (2013) Evaluation of soaking and foliar methods with compost tea, humic acid and bio-fertilizer on soil fertility and faba bean yield productivity and quality under saline soil condition. Minufiya J Agric Res 6(3):1663-1675

4. Aiyafar S, Poudineh HM, Forouzandeh M (2015) Effect of humic acid on qualitative and quantitative characteristics and essential oil of black cumin (Nigella sativa L.) under water deficit stress. DAV Int J Sci 4(2):89-102

5. Albano JP, Merhaut DJ (2012) Influence of FeEDDS, FeEDTA, FeDTPA, FeEDDHA, and FeSO4 on marigold growth and nutrition, and substrate and runoff chemistry. HortScience 47(1):93-97

6. Ali Z, Ahmad G, Rahman N (2001) Effect of zinc and manganese on the yield and quality of tomato. Pak J Biol Sci 4:156-157

7. Alrubaie JH, Alzaidi REK (2011) Effect of different nitrogen fertilizers doses and foliar fertilizers application on growth and yield of black cumin Nigella sativa. J Thi-Qar Univ 6(2):65-78

8. Ariafar S, Forouzandeh M (2017) Evaluation of humic acid application on biochemical composition and yield of black cumin under limited irrigation condition. Bull Soc R Sci de Liège 86:13-24

9. Arancon NQ, Edwarss CA, Bierman P (2006) Influences of aerated and non-aerated compost teas. J Food Agric Environ 5:302-309

10. Arancon NQ, Edwards CA, Dick R, Dick L (2007) Vermicompost tea production and plant growth impacts. Biocycle 48:51

11. Atiyeh RM, Lee S, Edwards CA, Arancon NQ, Metzger JD (2002) The influence of humic acids derived from earthwormprocessed organic wastes on plant growth. Biores Technol 84(1):7-14

12. Borowiec M, Polańska P, Hoffmann J (2007) Biodegradability of the compounds introduced with microelement fertilizers into the environment. Pol J Chem Technol 9(3):38-41

13. Buriro MA, Tayyab M (2007) Effect of Nigella sativa on lipid profile in albino rats. Gomal J Med Sci 5(1):10-15

14. Carpenter-Boggs L (2005) Diving into compost tea. Biocycle 46:61-62

15. Chapman HD, Pratt PF (1962) Methods of analysis for soils, plants and waters. Soil Sci 93(1):68

16. Chapman HD, Pratt PF (1978) Methods of analysis for soil plants and water. University of California Division of Agriculture Scientific Publishing 4034, p 19

17. Cottenie A, Verloo L, Kiens L, Velghe G, Camerlynch R (1982) Chemical analysis of plant and soils Lab Anal Agroch Fac Agric State University Gent, Belgium, p 63

18. El-Din AAE, Hendawy SF (2010) Effect of dry yeast and compost tea on growth and oil content of Borago officinalis plant. Res J Agric Biol Sci 6(4):424-430

19. El-Kholy MA, El-Bawab AM (1998) Response of some barley cultivars to nitrogen fertilization andstimophol as a foliar application. InProc. 8th Conf. Agron., Suez Canal University, Ismailia, Egypt, 145-152

20. El-Sherbeny SE, Hendawy SF, Youssef AA, Naguib NY, Hussein MS (2012) Response of turnip (Brassica rapa) plants to minerals or organic fertilizers treatments. J Appl Sci Res 8(2):628-634

21. Erdal I, Kepenek K, Kizilgos I (2004) Effect of foliar iron applications at different growth stages on iron and some nutrient concentrations in strawberry cultivars. Turk J Agric For 28:421-427
22. Fayed TA (2010) Effect of compost tea and some antioxidant applications on leaf chemical constituents, yield and fruit quality of pomegranate. World J Agric Sci 6:402-411

23. Gonález M, Gomez E, Comesea R, Quesada M, Contia M (2010) Influence of organic amendments on soil quality potential indicators in an urban horticultural system. Bioresour Technol 101:8897-8901

24. Hafez MH (1990) Influence of some agricultural treatments on majoram. M.Sc. thesis, Faculty of Agriculture, Mansoura University

25. Hendawy SF (2008) Comparative study of organic and mineral fertilization on Plantago arenaria plant. J Appl Sci Res 4(5):500-506

26. Hendawy SH, El-Sherbiny SE, Hussein MS, Khalid KA, Ghazal GM (2012) Response of two species of black cumin to foliar spray treatments. Aust J Basic Appl Sci 6(10):636-642

27. Hopkins WG (1999) Introduction to plant physiology, 2nd edn. Wiley, New York, pp 70-73

28. Hosseinzadeh H, Parvardeh S, Asl MN, Sadeghnia HR, Ziaee T (2007) Effect of thymoquinone and Nigella sativa seeds oil on lipid peroxidation level during global cerebral ischemia reperfusion injury in rat hippocampus. Phytomedicine 14(9):621-627

29. Hussain MZ, Khan MA, Ahmad SR (2006) Micronutrients status of Bannu Basin soils. Sarhad J Agric 22(2):283-285

30. Ibrahim Heba AK, Ibrahim SM (2014) Effect of some organic extracts on essential nutrients uptake of sugar beet under saline conditions. Res J Agric Biol 10(1):53-64

31. Jodice R, Luzzati A, Nappi P (1982) The influence of organic fertilizers, obtained from poplar barks on concentration of iron chlorosis of Lupinus albus L. Plant Soil 65(3):309-317

32. Katkat AV, Çelik H, Turan MA, Asik BB (2009) Effects of soil and foliar applications of humic substances on dry weight and mineral nutrients uptake of wheat under calcareous soil conditions. Aust J Basic Appl Sci 3(2):1266-1273

33. Kaya M, Atak M, Mahmood K, Cefci CY, Ozcan S (2005) Effect of pre-sowing seed treatment with zinc and foliar spray of humic acid on yield of common bean (Phaseolus vulgaris L.). Int J Agric Biol 7:875-878

34. Khalid K, Hendawy SF, El-Gezawy E (2006) Ocimum basilicum L. production under organic farming. Res J Agric Biol Sci 2:25-32

35. Khalil MY, Hussein MS, El-Sherbeny SE (2001) A comparative study on the effect of some foliar fertilizers on the growth, yield of Sinapis alba and Nigella sativa plants. Egypt J Hortic 28(3):371

36. Khan MA (1999) Chemical composition and medicinal properties of Nigella sativa Linn. Inflammopharmacology 7(1):15-35

37. Khan RU, Rashid A, Khan MS, Ozturk E (2010) Impact of humic acid and chemical fertilizer application on growth and grain yield of rainfed wheat (Triticum aestivum L.). Pak J Agric Res 23(3-4):113-121

38. Kim MJ, Shim CK, Kim YK, Hong SJ, Park JH, Han EJ, Kim JH, Kim SC (2015) Effect of aerated compost tea on the growth promotion of lettuce, soybean, and sweet corn in organic cultivation. Plant Pathol J 31(3):259-268

39. Klute A (1986) Water retention: laboratory methods. Methods of soil analysis: part 1-physical and mineralogical methods (methodsofsoilan1), pp 635-662

40. Lazcano C, Domínguez J (2011) The use of vermicompost in sustainable agriculture: impact on plant growth and soil fertility. Soil Nutr 10:1-23

41. Leithy SM (1998) Effect of soil type and micronutrients on growth, yield and chemical constituents of Nigella sativa L. Ph.D. thesis, Faculty of Agriculture, Mansoura University

42. Lutterodt $H$, Luther M, Slavin M, Yin JJ, Parry J, Gao JM, Yu LL (2010) Fatty acid profile, thymoquinone content, oxidative stability, and antioxidant properties of cold-pressed black cumin seed oils. LWT Food Sci Technol 43(9):1409-1413 
43. Mahmoud E, El-Gizawy E, Geries L (2014) Effect of compost extract, $\mathrm{N}_{2}$-fixing bacteria and nitrogen levels applications on soil properties and onion crop. Arch Agron Soil Sci 61:185-201

44. Marculescu A, Sand C, Barbu CH, Bobit D, Hanganu D (2002) Possibilities of influencing the biosynthesis and accumulation of the active principles in Chrysanthemum balsamita $\mathrm{L}$ species. Roum Biotechnol Lett 7(1):577-584

45. Mastouri F, Hassandokht MR, Padasht Dehkaei MN (2005) The effect of application of agricultural waste compost on growing media and greenhouse lettuce yield. Acta Hortic 697:153-158

46. Meshref HA, Rabie MH, El-Ghamry AM, El-Agamy AM (2010) Maximizing utilization of compost addition using foliar compost extract and humic substances in alluvial soil. J Soil Sci Agric Eng Mansoura Univ 1(9):957-971

47. Mohankumar AB, Gowda NN (2010) Effect of different organic manures and inorganic fertilizers on available NPK, microbial density of the soil and nutrient uptake of brinjal (Solanum melongena L.). Asian J Soil Sci 5(2):291-294

48. Nosir W, Abdelkader MA (2017) Effect of natural additives on Nigella sativa growth in hydroponic system. Future 2(4):11-30

49. Ouda BA, Mahadeen AY (2008) Effect of fertilizers on growth, yield, yield components, quality and certain nutrient contents in broccoli (Brassica oleracea). Int J Agric Biol 10(6):627-632

50. Pant AP, Radovich TJ, Hue NV, Talcott ST, Krenek KA (2009) Vermicompost extracts influence growth, mineral nutrients, phytonutrients and antioxida activity in pak choi (Brassica rapa cv. Bonsai, Chinensis group) grown under vermicompost and chemical fertiliser. J Sci Food Agric 89(14):2383-2392

51. Pant AP, Radovich TJ, Hue NV, Arancon NQ (2011) Effects of vermicompost tea (aqueous extract) on Pak Choi yield, quality, and on soil biological properties. Compos Sci Util 19(4):279-292

52. Pariari A, Sharangi AB, Chaterjee R, Das DK (2003) Response of black cumin (Nigella sativa L.) to the application of boron and zinc. Indian Agric 47:107-111

53. Pearson D (1976) The chemical analysis of foods. Longman Group Ltd, Harlow

54. Pharmacopoeia B (1963) Determination of volatile oil in drugs, vol 17. The Pharmaceutical Press, London, pp 112-125

55. Ramadan MF (2007) Nutritional value, functional properties and nutraceutical applications of black cumin (Nigella sativa L.): an overview. Int J Food Sci Technol 42(10):1208-1218

56. Rashid A, Ryan J (2004) Micronutrient constraints to crop production in soils with Mediterranean type characteristics: a review. J Plant Nutr 27:959-975
57. Rashid A, Yasin M, Ashraf M, Ali MA, Ahmed Z, Ullah R, Mann RA, Khan IA (2005). Alarming boron deficiency established in calcareous rice soils: boron use improves yield and cooking quality. In: Abstract book. 3rd international symposium on all aspects of plant and animal boron nutrition (boron 2005). Wuhan, China, 9-13 Sep. 78

58. Rodríguez-Ortíz JC, Valdez-Cepeda RD, Lara-Mireles JL, Rodríguez-Fuentes $\mathrm{H}$, Vázquez-Alvarado RE, Magallanes-Quintanar R, García-Hernández JL (2006) Soil nitrogen fertilization effects on phytoextraction of cadmium and lead by tobacco (Nicotiana tabacum L.). Biorem J 10:105-114

59. Russo VM, Fish WW (2012) Efficacy of microbial amendments on vegetables in greenhouse and field trials. HortScience 47:349-355

60. Shabnam J, Shahid AA, Haider MS, Umeera A, Ahmad R, Mushtaq $S$ (2012) Nutritional, phytochemical potential and pharmacological evaluation of Nigella Sativa (Kalonji) and Trachyspermum Ammi (Ajwain). J Med Plants Res 6(5):768-775

61. Sharafzadeh S, Ordookhani K (2011) Organic and bio fertilizers as a good substitute for inorganic fertilizers in medicinal plants farming. Aust J Basic Appl Sci 5(2):1330-1333

62. Sindhu SS, Tiwari RS (1993) Effect of micronutrients on yield and quality of onion (Allium cepa L.) cv. Pusa Red. Progress Hortic $25: 176-180$

63. Singh MV (1999) Current status of micro and secondary nutrients deficiencies and crop response in different ago-ecological regions. Experiences of all India coordinated research project on micro and secondary nutrients and pollutant elements in soils and plants. Fertil News 44:63-82

64. Snyman HG, Jong DE, Aveling TAS (1998) The stabilization of sewage sludge applied to agricultural land and the effects on maize seedlings. Water Sci Technol 38(2):87-95

65. Trough E, Mayer AH (1939) Improvement in the deiness calorimetric method for phosphorus and areseni. Indian Eng Chem Annu 1:136-139

66. Weltzien HC (1990) The use of composted material for leaf disease suppres-sion in field crop. Monogr Org Farming 45:115-121

67. Wreesmann C (1996) Chelated micronutrients for soilless culture. In: ISOSC proceedings, pp 559-572

68. Youssef AA (1998) Influence of brassinosteroid and zinc on growth, yield and seed composition of Nigella sativa. J Agric Sci Mansoura Univ 23(10):4551 